\section{AB0103 ACUTE PANCREATITIS AS INITIAL MANIFESTATION OF ANTI-PHOSPHOLIPID SYNDROME}

1J Qu, ${ }^{2} \mathrm{~K}$ Kankwenda, ${ }^{2} \mathrm{P}$ Ooghe, ${ }^{1} \mathrm{C}$ Gregoir. ${ }^{1}$ Rheumatology, CHU a Vesale, Montigny Le Tilleul, Belgium; ${ }^{2}$ Gastroenterology, CHU a Vesale, Montigny Le Tilleul, Belgium

10.1136/annrheumdis-2001.237

Background A 17 years old Belgian man was admitted with acute non-necrotic pancreatitis.

Laboratory data showed high levels of amylase and lipase, leucocytosis, erythrocyte sedimentation rate (ESR) $24 \mathrm{~mm} / \mathrm{h}$ and CRP $8.7 \mathrm{mg} / 100 \mathrm{ml}$, IgM against Epstein-Barr Virus (EBV) and lupus anticoagulant (detected according to the guidelines of International Society on Thrombosis and Haemostasis) were present. The evolution was spontaneously favourable and the diagnosis of acute pancreatitis on EBV infection was retained.

Objectives Four months later, recurrent abdominal pain appeared and the only positive clinical finding was a livedo reticularis.

Laboratory test showed a high ESR $(63 \mathrm{~mm} / \mathrm{h})$ but a normal CRP $(0.2 \mathrm{mg} / 100 \mathrm{ml})$, haemolytic anaemia, leucopenia, hypocomplementemia, presence of lupus anticoagulant, antinuclear antibody at 1/640 with anti dsDNA 517, EBV IgM antibody title has not changed.

Neither cutaneous nor renal involvement nor serositis was observed.

Mesenteric angioCT was normal.

The patient recovered under a treatment of steroids, anticoagulation and hydroxychloroquine.

Methods

Results Pancreatitis is a rare manifestation in the anti-phospholipid syndrome (APS) or systemic lupus erythematosus (SLE) and is often associated with severe multi-systemic complication and of poor prognosis.

Although the aetiology is not known, vasculitis lesion and thrombosis, adverse effect of steroid and azathioprine were thought to be the cause.

Conclusion We describe a case of pancreatitis as initial manifestation of APS, since ACR criteria for SLE are not fulfilled.

No further complication was observed at 2 months? followup.

The presence of EBV IgM antibody is probably due to polyclonal activation.

\section{REFERENCES}

1 Saab $S$, et al. Corticosteroids and systemic lupus erythematosus pancreatitis: a case series. J Rhumatol. 1998:25(4):801-6

2 Rojas-Serrano J, et al. Lupus patients in an emergency unit. Causes of consultation, hospitalization and outcome. A cohort study. Lupus 2000;9(8):601-6

\section{AB0104 ADRENAL INSUFFICIENCY PRIMARY ANTIPHOSPHOLIPID ANTIBODY SYNDROME AND AUTOIMMUNE HYPOTHYROIDISM}

R Foti, C Incognito, R Leonardi, S Fagone, L Bonincontro, P Castellino. Clinica Medica "L. Condorelli", Ospedale Vittorio Emanuele, Catania, Italy

\subsection{6/annrheumdis-2001.238}

Background Adrenal Insufficiency (A. I.) is an uncommon complication of the antiphospholipid antibody syndrome (APS). Several cases of A. I. are described in association with APS in patients with Systemic lupus erythematosus (SLE) or other connective tissue disease; in contrast A. I. in association with Primary Anthipospholipid Syndrome (PAPS) is seldom described.
Objectives We report a case of adrenal failure as first manifestation of APS and autoimmune hypothyroidism. Our patient is a 65 years old female who a month before was admitted to her local hospital for fever, cough and dyspnea. She had no previous history of thromboembolic or connective tissue disease. Chest radiograph showed an infiltrate and pleural effusion, which cleared over the next two weeks and she was discharged. Within few days, she developed nausea, vomiting, mild abdominal pain and fever. On admission to our hospital, she was deydrated with pulse of $110 / \mathrm{min}$, blood pressure $100 / 50 \mathrm{mmHg}$.

Methods Laboratory findings were: $\mathrm{Hb} 9.9 \mathrm{~g} / \mathrm{dl}$, WBC $16 \times$ $10 /^{3} \mu \mathrm{l}$, PLT $16710^{3} \mu / \mathrm{l}$, ESR $90 \mathrm{~mm} 1$ st h. Natremia was 128 $\mathrm{mEq} / \mathrm{l}$, kaliemia was $4.3 \mathrm{mmol} / \mathrm{l}$. Gastroscopy was normal, a CT scan revealed a bilateral enlarged adrenal gland with a normal cava and iliac and femoral vein. Anorexia, vomiting, weakness, weight loss, orthostatic hypotension and hyponatremia led us to suspect an adrenal insufficiency diagnosis, that was confirmed by a low plasma cortisol concentration $3.5 \mathrm{mg} / \mathrm{dl}$ (n. 6-30) and by an ACTH test. The serum ACTH concentration was $900 \mathrm{pg} / \mathrm{l}$ (n.6-46), aldosterone $<5 \mathrm{pg} / \mathrm{ml}$ (n. 7.5-150). APTT was 83.8 sec.(n. 20-40sec) with normal PT. Lupus anticoaugulant was positive, Antiphospholipid antibodies IgG were positive:21.4 U/ $\mathrm{ml}$ (n. <5). ANA, dsDNA and ENA were negative. TPHA, VDRL test, cryoglobulin and rheumatoid factor were negative. C3, C4 were normal. Antibodies against the adrenal cortex, tubercolin skin test and antibodies to HIV were negative. Thyroid hormones were: T3 $0.56(\mathrm{n} .0 .45-1.37 \mathrm{ng} / \mathrm{dl}) ; \mathrm{T} 4 \quad 5.0$ (n.4.50-12.00 ng/dl); FT3 1.90 (n.1.45-3.48 pg/ml); FT4 0.81 (n.0.71-1.85 ng/dl); TSH 7.44 (n.0.465-4.680 mUI/ml); TgAb 1:160; TMAb 1:160.

Results The diagnosis of AI secondary to PAPS associated with bilateral adrenal infarction, which was probably secondary to thrombosis of the adrenal glands veins, was made. In the course of hospitalisation the patient developed an extensive deep venous thrombosis of right iliac and femoral vein with estending up to the inferior vena cava. She was treated with hydrocortisone, fluorydrocortisone, heparin and L-thyroxine with rapid improvement in clinical and biochemical status.

Conclusion This case suggest that thrombosis of adrenal vein causing A. I. may be the first manifestation of PAPS and that the diagnosis of PAPS should be considered in patient with A. I; particular intriguing is the finding of autoimmune thyroid disease in a patient with A. I and PAPS.

\section{FRI0170 ANTICARDIOLIPIN ANTIBODIES IN SYSTEMIC RHEUMATIC DISEASES PATIENTS}

D Unikiene, A Baranauskaite, N Misiuniene. Department of Rheumatology, Kaunas University of Medicine Clinics, Kaunas, Lithuania

10.1136/annrheumdis-2001.239

Background Anticardiolipin antibodies (aCL) are quite common findings in patients with systemic rheumatic diseases. However, clinical significance of aCL presence still remains not completely clear despite some very well known clinical associations.

Objectives The purpose of our study was to evaluate clinical significance of aCL in our patients with systemic rheumatic diseases.

Methods We examined 242 pts who suffered from rheumatoid arthritis (RA), systemic lupus erythematosus (SLE), and systemic sclerosis (SS) and underwent treatment in Kaunas University of Medicine Rheumatology department. The control pts group 
(107 pts) was formed of healthy blood donors and pts without presence of any signs of rheumatic or immune disease. There were $216(89 \%)$ women and $26(11 \%)$ men aged 10 to 80 years (mean $51.4 \pm 14.6$ yr.) in study group. RA group consisted of $158(65.3 \%)$ pts, SLE - of $53(21.9 \%)$ pts, and SS group of 31 $(12.8 \%)$ pts. Diagnosis was evaluated according to standard American Rheumatology Association criteria. Enzyme immunoassay test to detect aCL IgG was performed in all pts.

Results Presence of aCL IgG was found in 38 (15.7\%) pts out of 242 pts in the study group and in $6(5.6 \%)$ control group pts. The incidence of aCL IgG was $30.2 \%$ in SLE pts, $29 \%$ in SS pts, and $8.2 \%$ in RA pts. There was significant difference in aCL IgG frequency between study pts and control groups, $p=0.009$, and between SLE and SS pts and control pts as well $(\mathrm{p}=0.000014$ and 0.0002 , respectively). However, there was similar aCL IgG incidence in RA and control pts.

Age of pts with positive enzyme immunoassay (EIA) test was significantly lower as compared with negative EIA test pts (mean age $45.8 \pm 15.8$ yr. and $52.5 \pm 14.1$ yr., respectively, $\mathrm{p}=$ $0.009)$. However, this difference appeared to be significant in SLE pts only $(p=0.02)$.

There was no significant difference in aCL IgG incidence in separate subsets of pts either in respect to sex, or disease activity, course, or duration. In fact, some clinical manifestations were strongly associated with the presence of aCL IgG. There was significant difference in incidence of livedo reticularis, subacute vein thrombosis, and thrombocytopenia between pts with positive and negative EIA test $(\mathrm{p}=0.015,0.0066,0.001$, respectively).

The diagnosis of secondary antiphospholipid antibody syndrome (APS) was confirmed in $15(6.2 \%)$ pts. There were 11 $(20.7 \%)$ pts in SLE group, 2 (6.4\%) pts in SS group, and 2 $(1.3 \%)$ pts in RA group with this condition. The majority of those pts were aCL IgG - positive ( $\mathrm{p}=0,0001$, as compared with aCL IgG - negative APS pts).

Conclusion 1) Presence of aCL IgG was associated with some clinical manifestations such as livedo reticularis, subacute vein thrombosis, and thrombocytopenia, and antiphospholipid antibody syndrome in pts with systemic rheumatic diseases, 2) There was no association found between presence of aCL IgG and pts sex, disease activity, course, or duration.

\section{FRI0171 LEVELS OF SOLUBLE VCAM-1, P-SELECTIN, AND E- SELECTIN IN PATIENTS WITH PRIMARY ANTIPHOSPHOLIPID SYNDROME AND SYSTEMIC LUPUS ERYTEMATOSUS}

AA Novikov, EN Alexandrova, TM Reshetnyak. Clinical Immunology, Cardiology Research Center, Moscow, Russia

\subsection{6/annrheumdis-2001.240}

Background The antiphospholipid antibodies (aPL) are known to modify the expression of adhesion molecules on activated endothelial cells and platelets in vitro and in vivo.

\section{Objectives}

Methods We studied the levels of soluble (s) P-selectin, sE-selectin, and sVCAM-1 by ELISA in sera from 19 patients (pts) $(5$ male, 14 female, mean age? $36.9 \pm 10.1$ years) with primary antiphospholipid sindrome (PAPS), 23 pts (10 male, 13 female, mean age ? $35.3 \pm 11.6$ years) with systemic lupus (SLE) erythematosus? related antiphospholipid sindrome (SLE-APS), 15 pts
(13 male, 2 female, mean age? $29.0 \pm 9.0$ years) with SLE and 38 controls.

Results The sE-selectin and sVCAM-1 concentrations were significantly higher in pts with PAPS, SLE-APS and SLE compared with controls. $(78.3 \pm 61.2 \mathrm{ng} / \mathrm{ml} ; 52.3 \pm 14.1 \mathrm{ng} / \mathrm{ml} ; 70.5 \pm$ $46.9 \mathrm{ng} / \mathrm{ml}$ vs $38.0 \pm 13.4 \mathrm{ng} / \mathrm{ml}$; $=0.0019, \mathrm{p}=0.0363, \mathrm{p}=$ 0.0144 , respectively for sE-selectin; $1003 \pm 582.6 \mathrm{ng} / \mathrm{ml}$; $1189.6 \pm 691.0 \mathrm{ng} / \mathrm{ml} ; 1227 \pm 680.2 \mathrm{ng} / \mathrm{ml}$ vs $594.7 \pm 63.3$ $\mathrm{ng} / \mathrm{ml} ; \mathrm{p}=0.0001$ for $\mathrm{sVCAM}-1)$.

The sP-selectin concentration was significantly higher in pts with SLE compared with controls (262.4 $\pm 158.8 \mathrm{ng} / \mathrm{ml}$ vs $120.1 \pm 53.7 \mathrm{ng} / \mathrm{ml} ; \mathrm{p}=0.0037)$. Within the group of pts with PAPS the sP-selectin concentration was higher among those with ischaemic CNS involvement. ( $\mathrm{p}<0.02)$.

The serum C-reactive protein level was positively correlated with the sE-selectin concentration in SLE-APS $(\mathrm{r}=0.341, \mathrm{p}<$ $0.05)$ and SLE $(r=0.699, p<0.01)$, the sVCAM-1 concentration in PAPS $(\mathrm{r}=0.705, \mathrm{p}<0.001)$ and SLE $(\mathrm{r}=0.405, \mathrm{p}<$ $0.05)$.

The serum, anti ds and ssDNA antibody level was positively correlated with the sP-selectin concentration in SLE-APS $(\mathrm{r}=$ 0.730 , and $\mathrm{r}=0.909, \mathrm{p}<0.001$ ), and the sE-selectin concentration in SLE $(r=0.684, p<0.001$ and $r=0.616, p<$ $0.002)$.

Conclusion The sE-selectin and sVCAM-1 concentrations were significantly higher in pts with PAPS, SLE-APS and SLE compared with controls. $(78.3 \pm 61.2 \mathrm{ng} / \mathrm{ml} ; 52.3 \pm 14.1 \mathrm{ng} / \mathrm{ml}$; $70.5 \pm 46.9 \mathrm{ng} / \mathrm{ml}$ vs $38.0 \pm 13.4 \mathrm{ng} / \mathrm{ml} ; \mathrm{p}=0.0019, \mathrm{p}=$ $0.0363, \mathrm{p}=0.0144$, respectively for sE-selectin; $1003 \pm 582.6$ $\mathrm{ng} / \mathrm{ml} ; 1189.6 \pm 691.0 \mathrm{ng} / \mathrm{ml} ; 1227 \pm 680.2 \mathrm{ng} / \mathrm{ml}$ vs $594.7 \pm$ $63.3 \mathrm{ng} / \mathrm{ml} ; \mathrm{p}=0.0001$ for sVCAM-1).

The sP-selectin concentration was significantly higher in pts with SLE compared with controls $(262.4 \pm 158.8 \mathrm{ng} / \mathrm{ml}$ vs $120.1 \pm 53.7 \mathrm{ng} / \mathrm{ml} ; \mathrm{p}=0.0037)$. Within the group of pts with PAPS the sP-selectin concentration was higher among those with ischaemic CNS involvement $(\mathrm{p}<0.02)$.

The serum C-reactive protein level was positively correlated with the sE-selectin concentration in SLE-APS $(r=0.341, p<$ $0.05)$ and SLE $(r=0.699, \mathrm{p}<0.01)$, the sVCAM-1 concentration in PAPS $(\mathrm{r}=0.705, \mathrm{p}<0.001)$ and SLE $(\mathrm{r}=0.405, \mathrm{p}<$ $0.05)$.

The serum, anti ds and ssDNA antibody level was positively correlated with the sP-selectin concentration in SLE-APS $(\mathrm{r}=$ 0.730 , and $\mathrm{r}=0.909, \mathrm{p}<0.001)$, and the sE-selectin concentration in SLE $(r=0.684, p<0.001$ and $r=0.616, p<$ $0.002)$.

\section{FRI0172 LONG-TERM FOLLOW-UP OF PAEDIATRIC PATIENTS WITH POSITIVE ANTI-PHOSPHOLIPID ANTIBODIES}

A Ince, A Roumany, U Daud, PH Pepmueller, TL Moore. Internal Medicine/Rheumatology, St Louis University Health Sciences Center, St Louis, USA

\subsection{6/annrheumdis-2001.241}

Background Long-term outcome data of Anti-Phospholipid syndrome (APLS) in paediatric patient population is very limited. There are no established criteria for making a diagnosis of Paediatric Anti- Phospholipid syndrome (APLS). Adult APLS criteria includes the major criteria of fetal loss, which is not pertinent to the pedriatric population.

Objectives To evaluate the clinical outcome of paediatric patients who either had a positive Lupus Anticoagulant (LAC), 